\title{
RECOGNITION AND ENFORCEMENT OF FOREIGN PROVISIONAL ORDERS IN THE UNITED STATES: TOWARD A PRACTICAL SOLUTION
}

\author{
S. NATHAN PARK 1
}

\begin{abstract}
Currently, the United States law lacks a coherent mechanism for providing recognition to, and allowing enforcement of, provisional orders issued by a foreign court. This paper argues for establishing a system for recognition and enforcement of foreign provisional orders in the United States. Such a system would confer three main benefits: (1) enhanced efficiency of transnational litigation in the U.S. courts; (2) appropriate allocation of judicial resource between U.S. and foreign courts that would promote both constitutional rights and judicial efficiency, and; (3) creation of the U.S.-led ecosystem of private international law. This paper then examines the three possible paths of establishing the system of foreign provisional order recognition: judicial, legislative, and treatybased. Although all three paths are viable, this paper argues that the treaty-based option provides the maximum flexibility necessary to reap the triple benefits of having a legal mechanism for recognition and enforcement of foreign provisional orders.
\end{abstract}

\footnotetext{
1 Career in Law Teaching Fellow, Columbia University School of Law; Adjunct Professor of Law, Georgetown Law Center; Of Counsel, Kobre \& Kim LLP. J.D., Columbia University School of Law 2007, B.A. University of California, Berkeley 2004. I would like to express my deep gratitude to Professors George Bermann, Carol Sanger and Julie Suk, as well as the academic fellows and associates in law at Columbia Law School, for their helpful comments in developing this paper.
} 


\section{TABLE OF CONTENTS}

1. Introduction: Provisional Orders in Transnational Set-

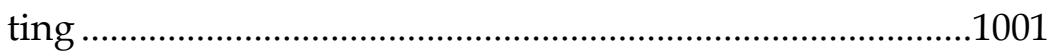

2. The Harm of Lacking a System for Recognition and Enforcement of Foreign Provisional Order: Two

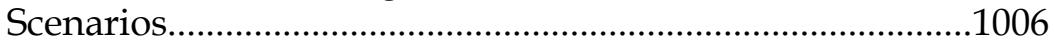

3. Why the United States Should Construct a System for Recognition and Enforcement of Foreign Provisional Orders: Three Benefits.............................................................1008

3.1. Foreign Provisional Order, Defined ..................................1008

3.2. Enhancing the Effectiveness of Transnational Litigation....1013

3.3. Efficient, and Appropriate, Allocation of Judicial Resources

3.4. Creation of U.S.-Led Ecosystem of Private International Law 1021

4. Designing the System of Recognition and Enforcement of Foreign Provisional Orders: Three Possibilities.............1031 4.1. Judicial Option: Resurrection of Hilton v. Guyot ...............1032 4.2. Legislative Option: UFMJRA as a Model ..... 1035 4.3. Treaty-Based Option: Flexibility and Customization ........1038

5. Conclusion: Toward a Practical Solution .............................1040 


\section{INTRODUCTION: PROVISIONAL ORDERS IN TRANSNATIONAL SETTING}

As international interactions of the United States and U.S. nationals increase, thousands of transnational litigation-lawsuits litigated within the national court system but with elements that reach beyond the national borders - are filed with the U.S. courts every year. ${ }^{2}$ However, transnational litigation in the United States often suffers from the lack of one of the basic litigation devices: provisional relief. Provisional reliefs, which maintain the status quo during the litigation, are particularly important in transnational litigation, because it is much easier to frustrate the enforcement of the court's final judgment when the case crosses the national border. ${ }^{3}$ A non-U.S. litigant, who wishes to ensure that the final judgment of the case (pending before a non-U.S. court) is satisfied, must often find herself in a situation in which she must preserve the status quo in the United States - typically in the form of defendants' asset located in the United States.

Although it is theoretically possible to obtain a provisional relief from a U.S. court to aid the main proceedings in a foreign country, such course of action is fraught with uncertainty and delay, which allow the defendant to upset the status quo yet again while the petition for a provisional relief is pending before the U.S. court. ${ }^{4}$ In the flip-side situation, in which a foreign litigant attempts to enforce a provisional order issued by a foreign court in the United States, the U.S. law provides virtually no guidance.

U.S. law does have several small pockets in which a U.S. court would recognize and enforce a provisional order issued by a for-

2 See ANDreW S. Bell, Forum Shopping AND VenUe In TransNational LiTIGATION 4 (2003) (“Quote simply, more international trade means more transnational disputes, contractual, quasi-contractual, and arising from the negligent provision of goods and services."). See Kevin M. Clermont \& Theodore Eisenberg, Xenophilia or Xenophobia in U.S. Courts? Before and After 9/11, 4 J. EMPIRICAL LEGAL STUD. 441, 462 (2007) (finding that, based on the data collected by the Administrative Office of the United States Courts, well over 120,000 alienage cases (i.e. dispute between citizens of a U.S. state and citizens or subjects of a foreign state, under 28 U.S.C. $\S 1332$ ) terminated in the United States federal district courts between 1986 and 2005. This figure does not include the transnational litigation that occurs at the state court level, which means the total volume of transnational litigation in American courts would be even higher).

3 See discussion infra at Section 3.2.

4 See discussion infra at Sections 2 and 3.1. 
eign court. In the areas of drug crimes or securities fraud, the United States is a party to bilateral and multilateral treaties that require the U.S. court to recognize and enforce foreign provisional orders. ${ }^{5}$ A scattershot of state courts have held that foreign provisional orders, usually issued in the areas of matrimonial and family law, are entitled to recognition and enforcement in the United States. ${ }^{6}$ And the few federal courts that considered this issue have held that recognition of a foreign provisional order may be theoretically possible, although they declined to actually recognize the foreign provisional order that appeared before them. ${ }^{7}$ Finally, Restatement (Second) of Conflict of Laws raises the possibility that the U.S. court may recognize and enforce foreign provisional orders under certain circumstances. ${ }^{8}$ For this proposition, however,

5 See, e.g., U.N. Convention Against the Illicit Traffic in Narcotic Drugs and Psychotropic Substances art. 7, 28 I.L.M. 493 (1989); Agreement Between the Government of the United States of America and the Government of the Republic of Singapore Concerning the Investigation of Drug Trafficking Offences and the Seizure and Forfeiture of Proceeds and Instruments of Drug Trafficking, U.S.-Sing., Nov. 3 2001, art. 10, T.I.A.S. No. 13125; Treaty on Mutual Assistance in Criminal Matters Between the United States and Switzerland, U.S.-Switz., May 23, 1973, 27 U.S.T. 2019; MOU Between the United States and Switzerland, U.S.-Switz., Aug. 31, 1978, 43 SEC Docket 14; Agreement XVI of the Swiss Bankers' Association with Regard to the Handling of Requests for Information from the SEC on the Subject of Misuse of Insider Information, U.S.-Switz., July 14, 1982, 43 SEC Docket 155; MOU on Exchange of Information Between the SEC and the UK Department of Trade and Industry in Matters Relating to Securities and Between the US Commodity Futures Trading Commission and the UK DTI in Matters Relating to Futures, U.S.-U.K., Sept. 23, 1986, 43 SEC Docket 176; Memorandum of the SEC and the Securities Bureau of the Japanese Ministry of Finance on the Sharing of Information, 43 SEC Docket 184 (May 23, 1986) (providing examples of such conventions that the U.S. is a party to).

6 See, e.g., Pacanins v. Pacanins, 650 So. 2d 1028 (Fla. Dist. Ct. App. 1995) (holding that a Venezuelan court order should be enforced in the U.S.). See also Cardenas v. Solis, 570 So. 2d 996 (Fla. Dist. Ct. App. 1990); Nahar v. Nahar, 656 So. 2d 225 (Fla. Dist. Ct. App. 1995); Wolff v. Wolff, 389 A.2d 413 (Md. Ct. Spec. App. 1978); Yoder v. Yoder, 330 A.2d 825 (Conn. Super. Ct. 1974) (providing more examples of various state courts recognizing foreign provisional orders).

7 See, e.g., Pilkington Bros. P.L.C. v. AFG Indus., Inc., 581 F.Supp. 1039, 1043 (D. Del. 1984); Air Prods. and Chems., Inc. v. Inter-Chem., Ltd., 2005 U.S. Dist. LEXIS 49198, * $18-21$ (E.D. Pa. Jan. 27, 2005) (providing examples of holdings that gave conditions under which an American court may recognize a foreign judgement). Compare Siko Ventures v. Argyll Equities LLC, 2005 U.S. Dist. LEXIS 21257 (W.D. Tex. Aug. 2005) (giving recognition to the final injunctive judgment rendered by the Hong Kong court), with the foregoing.

8 Restatement (SECOND) OF CONFlict OF Laws § 102, cmt. g (“It can . . . be assumed that a decree rendered in a foreign nation which orders or enjoins the doing of an act will be enforced in this country provided that such enforcement is 
the Restatement only cites a single state court case from the late 19th century, Roblin v. Long. ${ }^{9}$ The courts that did consider the Restatement's position nonetheless refused to recognize foreign provisional orders, noting the paucity of supporting authority in the Restatement. 10

Scholarly attention in this area of law has been likewise scant and scattered. For the most part, U.S. legal scholars have considered foreign provisional orders in the context of certain specific areas of the law-such as arbitration or intellectual property-but rarely as a standalone category as a general feature of private international law. 11 The few articles that do discuss provisional orders as an independent feature in transnational litigation are nearly twenty years old or older. ${ }^{12}$ Provisional orders are such a scholarly afterthought that the leading textbook in transnational litigation in the United States does not even have a chapter on provisional orders. ${ }^{13}$

necessary to effectuate the decree and will not impose an undue burden upon the American court.").

960 How. Pr. 200 (N.Y. Supp. Ct. 1880).

10 See, e.g., Pilkington, 581 F.Supp. at 1043 n.6, and Air Prods., 2005 U.S. Dist. LEXIS 49198 at *19 n.7 (providing examples of cases that did not recognize foreign judgments).

11 See, e.g., Richard Allan Horning, Interim Measures for Protection; Security for Claims and Costs; and Commentary on the WIPO Emergency Relief Rules (in Toto), 9 AM. REV. INT'L ARB. 155 (1998) (considering foreign provisional orders in the context of intellectual property law); Marketa Trimble, Cross-Border Injunctions in U.S. Patent Cases and Their Enforcement Abroad, 13 MARQ. InTELl. Prop. L. Rev. 331 (2009) (considering foreign provisional orders in the context of intellectual property law); Panagiota Kelali, Provisional Relief in Transnational Litigation in the Internet Era: What in the U.S. Best Interest?, 24 J. MARSHALl J. COMPUTER \& INFO. L. 263 (2006) (considering foreign provisional orders in the context of international commerce); Michael D. Mann, Paul A. Leder and Elizabeth Jacobs, The Establishment of International Mechanisms for Enforcing Provisional Orders and Final Judgments Arising from Securities Law Violations, 55 L. \& CONTEMP. PROBS. 303 (1992) (considering foreign provisional orders in the context of securities law); William Wang, International Arbitration: The Need for Uniform Interim Measures of Relief, 28 BROOKLYN J. INT'L L. 1059 (2003) (considering foreign provisional orders in the context of arbitration).

12 See, e.g., George A. Bermann, Provisional Relief in Transnational Litigation, 35 COLUM. J. TRANSNAT'L L. 553, 556-57 (1997) (exemplifying an article from 1997 that discuses provisional orders as an independent feature of transnational litigation); David Westin \& Peter Chrocziel, Interim Relief Awarded by U.S. and German Courts in Support of Foreign Proceedings, 28 COLUM. J. TRANSNAT'L L. 723 (1990) (presenting "a thumbnail sketch of the law in the United States and Germany on the availability of relief before judgment in support of foreign proceedings.").

13 Samuel P. Baumgartner, Book Review: Transnational Litigation in the United 
In assessing the state of the law, Professor George Bermann had commented in 1997 that the U.S. law on transnational provisional order was "far less well defined" than nearly all other conceivable topics in transnational litigation, including: deference to the jurisdiction of foreign courts or an arbitration panel; service of process abroad; collecting evidence abroad; recognition and enforcement of foreign final judgments, and; international anti-suit injunction. ${ }^{14}$ The situation has not improved in the two decades since Professor Bermann had made that comment, as there has been virtually no scholarly interest - much less judicial interest -in addressing the issue of constructing a coherent, generally applicable system of converting a provisional order obtained from a foreign court into an order that is enforceable in the United States. ${ }^{15}$

This under-development is problematic. In the subsequent parts, this paper will offer a more detailed analysis of why an absence of a general system for recognition and enforcement of foreign provisional orders presents a problem, and how the United States may construct such a system in a practical manner. Specifically, Part 2 of this paper will present two hypothetical scenarios involving provisional orders in transnational litigation, in which injustice and inefficiency arise because the U.S. law lacks the system for foreign provisional orders. These scenarios are based on real world events in order to highlight the exigency of the problem of injustice and inefficiency, and the necessity for a practical solution.

Part 3 will offer three principal benefits of formulating a coherent system of recognizing and enforcing foreign provisional orders. First, such a system would enhance the efficacy of transnational litigation, because provisional orders serve the crucial role of ensuring that litigation victory is not rendered pyrrhic. Such assurance

States, 55 AM. J. COMP. L. 793, 797-98 (2007) (reviewing Gary Born and Peter B. Rutledge, InTERnATIONAL Civil Litigation in United States COURTS, 4th ed. (2007)).

14 Bermann, supra note 12 , at 556-57.

15 Note, however, that from 1992 to 2002, the United States participated in the Hague Conference of Private International Law, which attempted to formulate a system that would have established a global system of enforcing provisional order and final judgment, as well as harmonizing the competing jurisdictions of the party states. However, the project was mostly focused on international jurisdiction and recognition of final judgments, with provisional orders as an afterthought. Further, for several reasons to be discussed below, the project failed. See discussion infra at Section 3.4. 
is particularly necessary in the context of transnational litigation, in which the barriers between different judicial systems hamper the effective vindication of legal rights. Second, having a coherent system of recognizing foreign provisional orders will lead to efficient allocation of judicial resources and protection of U.S. interests, by addressing situations in which the U.S. courts are involved either too much (leading to duplicative litigation) or too little (leading to leaving U.S. interests subject to foreign court's authority without U.S. court supervision.) Third, building a mutually enforceable system of recognizing foreign provisional orders may serve as the first step toward creating a U.S.-led judicial ecosystem, which would provide leverage for the United States in the formation of private international law that the European Union has hereto dominated.

Taking these three reasons into account, Part 4 will propose three possible means of creating a system that provides for recognition and enforcement of foreign provisional orders - judicial, legislative, and treaty-based - and assess the strengths and weaknesses of each. This paper will argue that while any one of the three means can be used to create a system of foreign provisional order recognition, the treaty-based option is the most preferable one. Although the judicial path remains a possibility under the Supreme Court case of Hilton v. Guyot,16 it is doubtful that the U.S. courts will actually take that path, as U.S. courts traditionally have shown very little inclination to view transnational litigation as a standalone category that warrants systematic consideration for the treatment of foreign court orders. The legislative path has a ready model for foreign provisional order in Uniform Foreign Money Judgment Recognition Act ("UFMJRA"), but the state-to-state variations in UFMJRA indicates that the legislative path is less than ideal for constructing a national system of recognizing foreign provisional orders. A treaty-based approach, in contrast, allows for a truly uniform treatment of foreign provisional orders throughout the United States. Further, a treaty can fully address the foreign policy implications of an international provisional order recognition regime, with maximum flexibility that would lead to a practical solution.

16153 U.S. 113 (1895). 


\section{THE HARM OF LACKING A SYSTEM FOR RECOGNITION AND ENFORCEMENT OF FOREIGN PROVISIONAL ORDER: TWO SCENARIOS}

How does the absence in the United States law of the system that uniformly handles foreign provisional orders prejudice transnational litigants? Consider the following two scenarios, based on real world examples:

\section{Scenario 1.}

Tycoon X, a Korean citizen who resides in Korea, is a wealthy businessman. Tycoon X's business began to falter with the economic downturn, which caused Tycoon $X$ to incur massive amount of debt. Instead of paying the debt, Tycoon X simply disappears, presumably leaving Korea. Creditors of Tycoon $X$-also Korean nationals who conduct business in Korea-sue Tycoon $X$ in a Korean court. The creditors then obtain a provisional attachment order from the Korean court against Tycoon X's property to secure the final judgment that the creditors are most likely to obtain eventually, given the certainty of debt and Tycoon X's failure to contest the debt.

As the creditors attempt to attach $X^{\prime}$ s assets, they find there is practically no property left in Korea to attach. As it turns out, Tycoon $\mathrm{X}$ personally owned little property as a formal matter; instead, various shell corporations located in the State of New York technically hold the bulk of Tycoon X's wealth. Tycoon X's children, who live in the State of New York as U.S. Permanent Residents (i.e. Green Card holders who retained their Korean citizenship,) control and manage the shell corporations. The creditors discover that, whenever Tycoon $X$ earned money in Korea, he siphoned the money to the U.S. in a manner that was fraudulent to Tycoon X's creditors. ${ }^{17}$

Although the Korean creditors of Tycoon X already litigated the debt before the Korean court and obtained a provisional relief from the court, the provisional order issued by the Korean court faces a terribly uncertain prospect in New York, because there is no

\footnotetext{
17 This example is loosely based on Korea Resolution and Collection Corporation v. Ahae Press, Inc. et al., Index No. 650349/2015 (N.Y. Sup. Ct. N.Y. County, filed Feb. 6, 2015). This author was the New York counsel for the plaintiff in the case.
} 
reliable legal rule - be it a statute, the Restatement or a New York precedent-under which a New York court would give effect to the Korean court's provisional order. For the sake of greater legal certainty, the Korean creditors institute a new action in New York to reach Tycoon $X^{\prime}$ s property. ${ }^{18}$ This action, theoretically, should have the same result as the New York court's recognition and enforcement of the Korean provisional relief. But practical considerations make a significant difference in reality: the time the Korean creditors took to search for a New York counsel, and the time the counsel spent preparing for a new round of litigation in New York, furnish Tycoon $X^{\prime}$ s children with ample opportunity to divert the asset to yet another jurisdiction.

\section{Scenario 2.}

Hotelier Y, a U.S. citizen who resides in New York, is sued in the United Kingdom, whose courts have personal jurisdiction over her. Based on the UK plaintiff's petition claiming that Hotelier $Y$ is attempting to frustrate the court's judgment by hiding assets, the UK court issues a provisional Mareva order on an ex parte basis, which prohibits Hotelier $Y$ from transferring or encumbering her assets in any way during the pendency of the litigation, on the pain of contempt. 19

Virtually all of Hotelier Y's property is located in New York, in the form of her hotel, bank accounts, accounts payable owed to her by her business counterparties, and so on. In an attempt to enforce the Mareva order, the UK plaintiff sends informal letters to Hotelier $\mathrm{Y}^{\prime} \mathrm{s}$ banks and business counterparties, who are third parties not subject to the UK court's jurisdiction. In the letter, the UK plaintiff demands that the third parties refrain from transferring any of $Y^{\prime} s$ assets in their possession. ${ }^{20}$

\footnotetext{
18 See Barclays Bank, S.A. v. Tsakos, 543 A.2d 802 (D.C. 1988) (providing an example of a U.S. court issuing a provisional order to assist a foreign proceeding).

19 See Mareva Compania Naviera v. Int'l Bulkcarriers S.A. (The Mareva), [1980] 1 All E.R. 213, 213 (Eng. C.A.) (explaining that Mareva is a court order, issued before the final judgment, that preserves the assets of a defendant who may dispose of her assets so as to defeat the final judgment). See Jeffery L. Wilson, Three if by Equity: Mareva Orders \& the New British Invasion, 19 ST. JOHN's J. LEGAL COMMENT. 673 (2005) (discussing potential extraterritorial abuses of Mareva orders).

20 This example is loosely based on CIBC Mellon Trust Co. v. Mora Hotel, NV, [2003] 1 All E.R. 564 and CIBC Mellon Trust Co. v. Mora Hotel Corp., 100
} 
Although the third parties -i.e., Hotelier Y's banks and business counterparts - are technically under no obligation to comply with the UK plaintiff's informal letter notifying the existence of the Mareva order (because the third parties are not subject to UK court's jurisdiction), the third parties nonetheless comply with the letter to avoid what they see as an unnecessary legal battle. As a result, Hotelier $Y$ suddenly finds herself unable to withdraw funds from her bank accounts or conduct transactions with her business counterparties on credit, which puts her business in dire straits. Because the UK court issued the Mareva order on an ex parte basis, Hotelier Y's assets are frozen without any notification to her, depriving her of the opportunity to contest the Mareva order in a hearing before her assets are frozen.

\section{WHY THE UNITED STATES SHOULD CONSTRUCT A SYSTEM FOR RECOGNITION AND ENFORCEMENT OF FOREIGN PROVISIONAL ORDERS: THREE BENEFITS}

\subsection{Foreign Provisional Order, Defined}

To define the term of art that is the heart of the discussion: what, precisely, is a "foreign provisional order"? The term is divisible into two parts: "foreign" and "provisional order." 21 For the purpose of this paper, the word "foreign" in "foreign provisional order" indicates that a foreign court issued the order. That is to say: this paper is not concerned with instances in which a U.S. court issues a provisional order in order to assist a foreign proceed-

\footnotetext{
N.Y.2d 215 (2003).

21 Certain international treaties governing transnational litigation use "provisional order" as a term of art. See, e.g., United Nations Convention on Independent Guarantees and Stand-by Letters of Credit, Art. 20, Dec. 11, 1997, 2169 U.N.T.S. 163, 196, https://treaties.un.org/doc/Publication/UNTS/Volume\% 202169/v2169.pdf [https://perma.cc/WL6G-PX7N] (listing circumstances under which the court may issue a provisional order). This paper, however, gives its own definition of "provisional order" and does not strictly adhere to a preexisting, technical definition that may be embodied in an international treaty, statute or the like, although this paper's definition of the term may be broadly consistent with pre-existing understandings of the nature of provisional orders. See discussion infra in this section.
} 
ing. ${ }^{22}$ Indeed, this is the circumstance described in Scenario 1 above, as the Korean plaintiffs are seeking a provisional order from New York state court to assist a proceeding before a Korean court. However, as Scenario 1 demonstrates, having the U.S. court issue a provisional order to assist foreign litigation invites duplicative litigation, and gives the defendant the time to frustrate the judgment. ${ }^{23}$ Instead, this paper considers the system in which the litigant first obtains a provisional order from a foreign court, and a U.S. court would domesticate the foreign provisional order by providing a summary procedure for recognition and enforcement. ${ }^{24}$

The term "provisional order" in "foreign provisional order," for the purpose of this paper, indicates all interim reliefs that a court may grant prior to the final judgment. This definition is purposefully inclusive such that it does not necessarily depend on the technical categorization that a foreign legal system may make concerning a particular type of interim relief. For example, there is considerable debate as to how one may classify a Mareva order, which is a feature in many Common Law jurisdictions such as the United Kingdom, Canada and Australia. ${ }^{25}$ As discussed above, Mareva order is a court order, issued before the final judgment, which preserves the assets of a defendant who may dispose of her assets so as to defeat the final judgment. The courts that utilize Mareva orders have generally characterized the order as a judg-

\footnotetext{
22 See Tsakos, 543 A.2d 802 (holding that jurisdiction exists, noting the possibility of staying the action pending completion of litigation in Europe, reversing the dismissal and remanding for further consideration).

23 For further discussion regarding the disadvantage of a U.S. court issuing provisional relief to assist a foreign proceeding, see discussion infra at Section 3.3.

24 As discussed further below, this proposed system is akin to U.S. law's treatment of foreign final judgments. See discussion infra at Section 4.2. For an example of a statute providing for summary recognition of foreign money judgments, see, e.g., N.Y. C.P.L.R. § 5301-09 (McKinney's Consolidated Laws of New York Annotated) (providing statutory recognition of foreign country monetary judgments in New York).

25 See David L. Zicherman, The Use of Pre-Judgment Attachments and Temporary Injunctions in International Commercial Arbitration Proceedings: A Comparative Analysis of the British and American Approaches, 50 U. PITT. L. REV. 667, 674 (1989) (collecting different characterizations of a Mareva order). Although the United States is a Common Law jurisdiction, the Supreme Court of the United States held that a Mareva order is not available under the U.S. law. See Grupo Mexicano de Desarrollo, S. A. v. Alliance Bond Fund, Inc., 527 U.S. 308, 327-28 (1999) ("the relief sought by respondents does not have a basis in the traditional powers of equity courts").
} 
ment, rather than an interim relief. In the case of Mareva Compania Naviera v. Int'l Bulkcarriers S.A. (The Mareva), Lord Denning considered a Mareva order to be an "interlocutory judgment." 26 Subsequent English cases have held that a Mareva order is not a provisional relief, on a rather technical basis that it is an in personam injunction that commands the defendant as to what she may do with her assets, rather than an order that authorizes the seizure of the asset.27 Similarly, the High Court of Australia has held that a Mareva order should not be considered under the law of injunctions, instead characterizing it as "asset preservation orders." 28 Yet legal scholars have noted that the essential function of a Mareva order is provisional, in that a Mareva order only serves to assist the plaintiff in her prosecution of a different litigation (the "main litigation") without affecting the decisions on the merits of that litigation. ${ }^{29}$

For the purpose of this paper, the characterization by a foreign legal system need not be determinative. In the spirit of pragmatism, this paper eschews navigating the thicket of whether a foreign legal system considers a particular pre-judgment relief a "provisional relief" under its system of the law. Instead, this paper

26 Mareva Compania Naviera SA v International Bulkcarriers SA, [1980] 1 All E.R. 213, 213 (Eng. C.A.).

27 See Cretanor Maritime Co. Ltd. v. Irish Marine Mgmt. Ltd., [1978] 1 W.L.R. 966, 974 (Eng. C.A.) ("A Mareva injunction . . . is relief in personam. It does not effect a seizure of any asset. It merely restrains the owner from dealing with the asset in certain ways."); Iraqi Ministry of Defence v. Arcepey Shipping Co. S.A., [1981] Q.B. 65, 72, [1980] 2 W.L.R. 488 (1979) (Eng. Q.B.) ("the point of the Mareva jurisdiction is to proceed by stealth, to pre-empt any action by the defendant to remove his assets from the jurisdiction. To achieve that result the injunction must be in a wide form because, for example, a transfer by the defendant to a collaborator in the jurisdiction could lead to the transfer of the assets abroad by that collaborator. But it does not follow that, having established the injunction, the court should not thereafter permit a qualification to it to allow a transfer of assets by the defendant if the defendant satisfies the court that he requires the money for a purpose which does not conflict with the policy underlying the Mareva jurisdiction.").

28 Cardile v. LED Builders Pty Ltd., [1999] 198 C.L.R. 380, 393 (Austl.).

29 See Michael Tillbury, Remedy Discussion Forum: Teaching Remedies in Australia, 39 BRANDEIS L.J. 589, 590 (2001) (as "a Mareva assists a right which may be established in the case," a Mareva order is "part of the armour of prejudgment enforcement of remedies"); Lars E. Johansson, The Mareva Injunction: A Remedy in the Pursuit of an Errant Defendant, 31 U.C. DAVIS L. REV. 1091, 1103-04 (1998) (discussing Mareva order's function as a prejudgment attachment); Peter S. O'Driscoll, Performance Bonds, Banker's Guarantees, and the Mareva Injunction, 7 NW. J. INT'L L. \& Bus. 380, 398 (1985) (same). 
opts for a functional definition: any interim remedy, issued in order to preserve the status quo or to secure assets out of which an ultimate judgment may be satisfied, either during the pendency of litigation or shortly before litigation begins, is considered a "provisional order" in this paper. ${ }^{30}$ This functional definition has the advantage of flexibility, such that the definition accommodates the real-world context in which provisional reliefs appear in modern transnational litigation. That is to say, regardless of the precise iteration that a provisional relief may take (for example, a provisional order may be applied in personam or in rem,) the purpose of the provisional order is invariably to control the defendant's behavior and preserve the status quo in some way. ${ }^{31}$

In addition to its practical advantage, this definition is consistent with the manner in which the existing private international law scholarship understands the nature of provisional orders, although the precise terms of art and the context in which they appear may differ. For example, International Law Association defines a "provisional order" as interim measures that "perform two principal purposes in in civil and commercial litigation: (a) maintain the status quo pending determination of the issues at trial; or (b) to secure assets out of which an ultimate judgment may be satisfied." 32 This paper's definition of "provisional order" is also similar to the definition of "interim measures" in UNCITRAL Model Law on International Commercial Arbitration, which defines "interim measures" as

any temporary measure ... . by which, at any time prior to the issuance of the award by which the dispute is finally decided, the arbitral tribunal orders a party to: (a) maintain or restore the status quo pending determination of the dispute; (b) take action that would prevent, or refrain from taking action that is likely to cause, current or imminent harm or prejudice to the arbitral process itself; (c) provide a means of preserving assets out of which a subsequent

30 For discussion regarding the essential character that all types of provisional orders commonly share, see infra at Section 3.3.

31 For examples of an in personam remedy used interchangeably with an in rem remedy to achieve the same result of preventing asset dissipation by the defendant, see Wilson, supra note 19.

32 Friedrich K. Juenger, The ILA Principles on Provisional and Protective Measures, 45 AM. J. CoMP. L. 942, 942 (1997). 
award may be satisfied; or (d) preserve evidence that may be relevant and material to the resolution of the dispute. ${ }^{33}$

In transnational litigation, provisional orders may take a number of different forms, including but not limited to: attachment of defendant's assets to secure the final judgment; ${ }^{34}$ protection of the subject matter of the dispute; 35 preservation of evidence; ${ }^{36}$ anti-suit injunction, ${ }^{37}$ and so on. From a global perspective, each form of provisional order in each legal system may differ from another provisional order in another legal system in any number of ways, including: bases of jurisdiction (e.g., in rem versus in personam); intra- versus extra-territorial reach (e.g., attachment of a fixed piece of real property versus a global Mareva order); severity of the remedy (e.g., holding funds for several days versus raiding a place of business for evidence); level of continuing court supervision (e.g.,

33 Comm. on Int'l Trade Law, UNCITRAL Model Law on International Commercial Arbitration 1985: With Amendments as Adopted in 2006, at Ch. IV Section 1, U.N. Pub. E.08.V4 (2008), http://www.uncitral.org/pdf/english/ texts/arbitration/ml-arb/07-86998_Ebook.pdf [https://perma.cc/KN6K-CSUX].

34 See, e.g., Federal Court Rule 2011 (Cth) pt 7.32 (Austl.); Civil Procedure Rules, 1998, S.I. 1998/3132, Part 25.1, q 1(l) \& (m) (Eng.); CodE DE Procedure Civile [C. civ.] art. 515 (Fr.); ZivilProzessordnung[ZPO] [CODE OF CIVIL PROCEDURE], Jan 30, 1877, ReichSGESETZBLATt [RGBLL] 83, as amended, § 917, para. 1 (Ger.); MinJI HOZEN-HO [CIVIL PROVISIONAL REMEdiEs LAW] 1989, art. 20 (Japan); Minsa jiphaeng beob [Civil Procedure], Act. No. 10629, May 19, 2011, art. 277-jo (S. Kor.).

35 See, e.g., Federal Court Rule 2011 (Cth) pt 7.33 (Austl.); Civil Procedure Rules, 1998, S.I. 1998/3132, Part 25.1, ॠף 1(c)(i)-(iii) \& (e) (Eng.); CODE DE Procedure Civile [C. civ.] art. 849 (Fr.); ZivilPrOZESSORDNung[ZPO] [CODE OF Civil Procedure], Jan 30, 1877, ReichsgeSETZblatt [RGBLl] 83, as amended, § 942, para. 1 (Ger.); MiNJI HOZEN-HO [CIVIL PROVISIONAL REMEDIES LAW] 1989, arts. 23-24, 53-55, 58-65 (Japan); Minsa jiphaeng beob [Civil Procedure], Act. No. 10629, May 19, 2011, art. 300-jo (S. Kor.).

36 See, e.g., Federal Court Rule 2011 (Cth) pt 7.32 (Austl.); Civil Procedure Rules, 1998, S.I. 1998/3132, Part 25.1, q 1(d) \& (h)-(j) (Eng.); CODE DE Procedure Civile [C. civ.] art. 134 (Fr.); ZivilProzessordnung[ZPO] [CODE OF CIVIL Procedure], Jan 30, 1877, ReICHSGESETZBLATt [RGBLL] 8, as amended, § 372 (Ger.); Minji SOSHOHO [Minsoho][C. CIV. Pro.] 1996. art. 234 (Japan); Minsa sosong beob [Civil Procedure], Act. No. 10629, May 19, 2011, art. 379-jo (S. Kor.).

37 See, e.g., CSR Am. Inc. v. Cigna Ins. Australia Ltd. [1997] 146 ALR 402 (Austl.) (discussing principles governing grant of interlocutory anti-suit injunctions restraining proceedings in foreign courts); Amchem Prods. Ltd. v. British Columbia (Workers' Compensation Bd.), [1993] 1 SCR. 897 (Can.) (same); Societe Nationale Industrielle Aerospatiale v. Lee Kui Jak, [1987] 1 AC 871 (P.C.) (Eng.) (same). An antisuit injunction would fall under this paper's expansive definition of "provisional order," although an anti-suit injunction essentially deals with matters of jurisdiction, especially in the transnational context. See discussion infra at Section 4.3. 
one-time halt of asset disposition versus receivership of a corporation,) and so on. But two commonalities thread this wide-ranging diversity of provisional orders across the world: (1) all provisional orders attempt to preserve the status quo in some manner while the main action is pending; and (2) virtually all modern legal systems have some form of the reliefs described in the foregoing, whether or not such legal systems technically categorize them as "provisional orders." These two commonalities allow for the creation of a system of recognition and enforcement of foreign provisional orders.

By constructing a general system of recognizing and enforcing foreign provisional orders, the United States stands to benefit in three major ways: (1) enhance the effectiveness of transnational litigation; (2) promote efficient allocation judicial resources, and; (3) take the first step toward creating a U.S.-led ecosystem of private international law in this area.

\subsection{Enhancing the Effectiveness of Transnational Litigation}

As discussed above, provisional orders come in many different forms before and during the pendency of litigation. Yet all provisional orders share a common goal: enhancing the efficacy of litigation. Securing the satisfaction of the forthcoming judgment, protecting the subject of the litigation while litigation is ongoing, searching the premises to preserve the evidence that may be destroyed-assuming the plaintiffs' contentions are meritorious, all of the foregoing measures are necessary to ensure that the lawsuit can practically deliver the desired end result by preserving the status quo or status ex ante while the litigation is pending. ${ }^{38}$

This necessity is particularly acute in contemporary transnational litigation. ${ }^{39}$ There is a good reason why the first impulse of a person who wishes to run from the law is to flee the country. Thanks to ever-increasing international commerce and advancements in technology, it takes mere seconds to move money across

\footnotetext{
38 See Bermann, supra note 12, at 559 ("a broader purpose of provisional orders" is to "help preserve the status quo pending litigation.").

39 See Westin \& Chrocziel, supra note 12, at 723 (" parties embarking on litigation with foreign parties must often [fear] that, unless restrained, their adversaries will take actions that will make ultimate victory pyrrhic.").
} 
the border, and mere hours to move a person. The same cannot be said about the legal process, although the legal process is tasked with regulating the movement of assets and people in order to vindicate legal rights. Because court orders do not travel as quickly and seamlessly as money and people do, "[t]he fact that one party may have a weak link with the country of the forum ... tends to increase the pressure to settle or quit," as Professor Gerry Maher noted. ${ }^{40}$ Accordingly, Maher notes that "in international litigation the place of provisional remedies may well be even more significant" compared to domestic litigation. ${ }^{41}$ This is particularly true when the subject of the litigation is an especially modern and ephemeral one, such as intellectual property. Because it is so easy to place evidence of intellectual property infringement beyond the reach of the plaintiff, and the effect of the infringement difficult to quantify in monetary terms, "quickly obtained injunctions and other relief orders are often the only real remedy." 42

Because the United States law has no general system of addressing foreign provisional orders, litigants who obtained an interim relief from a foreign court lack these critical protections afforded by provisional remedies. This leads to instances of obvious injustice. Scenario 1, discussed above, is an illustration of such an instance. In Scenario 1, the Korean creditors of Tycoon $X$ already have a provisional attachment order from the Korean court, but that order is useless in Korea as a practical matter (because there is no asset in Korea,) and useless in the U.S. as a legal matter (because it is highly unlikely that a U.S. court will recognize and enforce the order.) For any chance at having their loans repaid, the creditors most likely have to institute an entirely new action before the New

\footnotetext{
40 Gerry Maher \& Barry J. Rodger, Provisional and Protective Remedies: the British Experience of the Brussels Convention, 48 INT'L \& COMP. L. Q. 302, 303 (1999).

41 Id.

42 Horning, supra note 11, at 155-56. See also David Capper, The Need for Mareva Injunctions Reconsidered, 73 FORDHAM L. REV. 2161, 2179 (2005) ("the United States very likely experiences the same problems that led eminent jurists around the world to fashion a remedy to protect litigants from unsatisfied judgments and courts from having their process stultified. ... If the United States declined to recognize the Mareva injunction there may be a risk that it becomes a haven for persons determined to evade their legal responsibilities to deposit their assets."). For additional discussion on the particular importance of provisional orders in transnational litigation in the context of the use of the Internet, see Kelali, supra note 11 .
} 
York court, which has jurisdiction over the fraudulently transferred property. Meanwhile, the children of Tycoon $X$ are free to upset the status quo by transferring the property to yet another jurisdiction, rendering satisfaction of Tycoon $X^{\prime}$ s debt impossible as a practical matter.

It may be argued that expanding the availability of provisional reliefs should be approached with caution. This argument has some force as a general matter, because the ease with which the petitioner may obtain a provisional order inevitably affects the balance of power between the plaintiff and the defendant. Plainly, a provisional order restricting the defendant's activities (including disposition of defendant's property) provides a great deal of practical leverage to the plaintiff. For example, if the plaintiff manages to freeze the defendant's assets before the litigation commences, the plaintiff may gain a significant advantage by putting the defendant into a financial straitjacket. This may lead to an intense settlement pressure, under which the defendant may be forced into a settlement without regard to the actual merits of the case. This re-calibration of relative power balance between plaintiffs and defendants has a significant impact in creditor-debtor relationship, as creditors generally rely on the courts to obtain satisfaction of unpaid debts. Writ large, the shifting power balance between plaintiffs and defendants (who are usually creditors and debtors respectively,) caused by greater availability of provisional measures, may evolve into a political issue. Indeed, debtors have always been an important constituency in American law and politics. ${ }^{43}$ Partially because the English bankruptcy law that early American colonialists had left behind was so draconian, the United States law has been consistently friendly to the debtor to a point that it is accused of coddling debtors. ${ }^{4}$

But in the context of transnational litigation, this concern is overstated. As a threshold matter, any system under which the United States judiciary recognizes and enforces a foreign provisional order would come with defenses against such recognition and enforcement, as per the requirement of the Due Process Clause of the United States Constitution. ${ }^{45}$ Further, compared to her coun-

43 See generally Charles E. Dorkey III, 'Grupo Mexicano' N.Y.L.J. June 8, 2000.

44 See id.

45 See U.S. CONST. amend. V; U.S. CONST. amend. XIV, § 1; Sniadach v. Family Fin. Corp., 395 U.S. 337 (1969) ("prejudgment garnishment of wages procedure, 
terpart in domestic litigation, the plaintiff in transnational litigation - like the Korean creditors in Scenario 1-can exert little leverage through a provisional relief in the United States, precisely because there is no mechanism for obtaining one that is practically useful. Even the most debtor-friendly jurisdiction, such as the United States, would not countenance a situation in which the creditor has no recourse through a provisional relief against a debtor who is determined to evade his debt-a frequent occurrence in the context of transnational litigation. ${ }^{46}$ Stated differently, establishing a system of recognizing foreign provisional orders does not grant any special power to a transnational plaintiff that is above and beyond what is commonly available in the domestic setting. At most, such a system would shore up the efficacy of transnational litigation to be on the same level as domestic litigation. Considering the critical importance that provisional reliefs play in transnational litigation, such shoring up is long overdue. In the interest of justice, there needs to be a system through which a foreign provisional order may be domesticated for enforcement in the United States.

\subsection{Efficient, and Appropriate, Allocation of Judicial Resources}

The second benefit of recognizing foreign provisional orders is that it leads to efficient and appropriate allocation of foreign and domestic judicial resources. Through the doctrine of forum non conveniens, the U.S. law has expressed its desire to ensure appro-

with its obvious taking of property without notice and prior hearing, violates the fundamental principles of procedural due process" ... "the wage earner [would be] deprived of his enjoyment of earned wages without any opportunity to be heard and to tender any defense he may have, whether it be fraud or otherwise."). For comparison, most U.S. laws providing for recognition and enforcement of foreign court's final judgment in the United States have a set of defenses to which the party resisting recognition and enforcement may resort. See, e.g., N.Y. C.P.L.R. § 5304 (McKinney's Consolidated Laws of New York Annotated) (providing grounds for non-recognition of foreign judgement). For additional discussion on potential defenses against recognition and enforcement of foreign provisional orders, see discussion infra at Section 4.

46 Indeed, the U.S. law does allow a creditor to rely on a provisional relief to ensure that defendant satisfies the final judgment that the court would render eventually. See, e.g., Fed. R. Civ. P. 64 (authorizing seizure of a person or property to secure satisfaction of the potential judgment). 
priate allocation of judicial responsibility between foreign and domestic courts, even though the case may technically satisfy the requirements for U.S. court jurisdiction and venue. ${ }^{47}$ In applying the forum non conveniens doctrine, the U.S. court assesses which jurisdiction has the greater interest in adjudicating the case by analyzing the nationalities of the parties in interest, the location of the witnesses and evidence, public interest of the forum in relation to the events giving rise to the litigation, etc. ${ }^{48}$ Through this analysis, the U.S. law promotes efficient allocation of judicial resources, discourages forum shopping from plaintiffs, ${ }^{49}$ and prevents the possibility of "race to judgment" by potentially allowing parallel litigations in two different fora. 50

Precisely the same benefits would inure if the U.S. law establishes a system to recognize foreign provisional orders. Consider Scenario 1: the connection between the main litigation and the State of New York is quite tenuous, as the only connection of the case to the New York forum is that the defendant hid his property in the State of New York. In a sense, one can argue that Tycoon $\mathrm{X}$ engaged in an indirect type of forum shopping by choosing to place his property in New York so as to frustrate his creditors. But for the New York property, it is likely that a case filed with the

47 See generally Jack H. Friedenthal, Mary Kay Kane \& ARTHUR R. Miller, Civil Procedure § 2.17 (3d ed. 1999); 17 James WM. MoOre et AL., MoOre's FEDERAl PRACTICE $§ \S 111.70-.95$ (3d ed. 1997); 15 CHARles Alan Wright, ARTHUR R. Miller \& EdWARD H. COOPER, Federal Practice AND Procedure $§ 3828$ (2d ed. 1986 \& Supp. 2003). For detailed discussion regarding the way in which the courts employ forum non conveniens doctrine to allocate judicial responsibility between foreign and domestic courts, see Christopher A. Whytock, The Evolving Forum Shopping System, 96 CORNELL L. REV. 481, 516-28 (2011).

48 See Piper Aircraft, Inc. v. Reyno, 454 U.S. 235 (1981) (considering location of parties, location of witnesses, location of potential third parties to be impleaded, etc. to dismiss a case based on forum non conveniens).

49 See Daniel J. Dorward, The Forum Non Conveniens Doctrine and the Judicial Protection of Multinational Corporations from Forum Shopping Plaintiffs, 19 U. PA. J. INT'L ECON. L. 141, 158 (1998) (arguing "that the use of the forum non conveniens doctrine has evolved to solve the peculiar problems posed by international forum shopping and that U.S. courts should continue to make pragmatic use of the doctrine to protect MNCs from the burdens of defending foreign suits in the United States.").

50 See Roland A. Brand, Tug of War: The Tension Between Regulation and Internal Cooperation: Challenges to Forum Non Conveniens, 45 N.Y.U. J. INT'L L. \& PoL. 1003, 1008 (2013) (discussing recent internal and external challenges to the forum non conveniens doctrine and where the evolutionary development of the doctrine might go in the future). 
New York court in relation to Scenario 1 would be dismissed on forum non conveniens grounds, as all the parties in interest are Korean nationals (recall that even Tycoon $X^{\prime}$ s children are Korean nationals,) the defendant Tycoon $X$ incurred the debt in Korea, and all relevant witnesses and documentary evidence are located in Korea. 51

Establishing a system of recognizing foreign provisional orders is the best way to address this concern. Theoretically, it is possible for the Korean creditors in Scenario 1 to petition the New York court to issue the provisional relief while the litigation in Korea is ongoing. ${ }^{52}$ However, as discussed above, this gives time for the debtor defendant to abscond with the property to another jurisdiction that the creditor cannot reach. In addition, to analyze whether the plaintiff may obtain a provisional relief, the New York court must analyze the main proceeding's likelihood of success, as required by New York law. ${ }^{53}$ (Indeed, majority of jurisdictions in the United States requires the court to assess the likelihood of success of the main action before issuing provisional relief.) ${ }^{54}$ This means that the New York court is put in the uncomfortable position of assessing the likelihood of success for the plaintiff's litigation pending in Korea. In other words, not only do the creditors have to relitigate the same lawsuit that they already won in a different forum, but also they must rely on the New York court, which is not familiar with Korea's law, business custom or language, to analyze the litigation pending in Korea, in order to render the correct result. (Which, in this case, is the issuance of a provisional order because of the risk of the defendant's fraudulent transfer.) If the New York court should rule erroneously, it would create a result that is inconsistent with the main litigation pending in Korea, as the Korean court already issued an attachment order in Scenario 1.

In the interest of judicial economy and justice, a summary procedure in which Tycoon X's creditors can simply bring the provisional order that the Korean court issued, and obtain recognition of

51 See Piper Aircraft, 454 U.S. at 241-43.

52 See, e.g., Tsakos, 543 A.2d 802.

53 See N.Y. C.P.L.R. § 6212(a) (McKinney's Consolidated Laws of New York Annotated) (detailing plaintiff's burden on a motion for an order of attachment).

54 See, e.g., CAL. Civ. Proc. § 484.090(a)(2); Fla. Stat. § 76.24(1); Mass. R. Civ. P. 4.1(c); N.J. PRAC. CT. R. 4:60-5(a)(1); but see CONN. GEN. STAT. § 52-278d(a) (a "probable cause" standard for obtaining attachment, which is significantly lower than the "likelihood of success on the merits" standard). 
the order from the New York court, would be preferable. Of course, Tycoon $\mathrm{X}$ and his children-debtor and garnishees, respectively - would be able to raise defenses to resist the recognition. Once the Korean provisional order is recognized, the creditors would be able to enforce the order in New York, as if a New York court issued the order. Indeed, in many states, that is precisely how it works with certain types of foreign final judgments. 55 Such a procedure would avoid duplicative litigation, give the creditors a realistic chance to arrest the property, and spare the U.S. courts from having to venture into a foreign case and foreign law.

Recognition of foreign provisional orders, however, is not only geared toward avoiding the involvement of U.S. courts. Scenario 2 depicts the rarer, but realistic, situation in which U.S. courts should be more involved in the enforcement of foreign provisional orders. Whereas the New York court is involved too much in Scenario 1, it is not involved enough in Scenario 2. The UK court's provisional order in Scenario 2 did not simply infringe upon the property rights of a New York resident and a U.S. citizen; it also sought to bind third parties such as Hotelier Y's banks and business counterparts, who are not under the UK court's jurisdiction. The UK plaintiffs obtained a provisional order from the UK court on ex parte basis, and sought to enforce the order ex parte as well by sending informal letters rather than formally serving process. As a result, Hotelier $\mathrm{Y}$ is deprived of the use of her property, which is located outside of the UK court's jurisdiction. All of the foregoing violates $\mathrm{Y}^{\prime}$ s constitutional rights for Due Process. ${ }^{56}$

In addition to violating Hotelier Y's constitutional rights, the UK plaintiff's behavior in Scenario 2 is the antithesis of orderly administration of justice. If Scenario 2 occurred in the United States as an entirely domestic matter, the plaintiffs would have had to follow the New York state law providing for a restraining order and garnishment, which protects the property interest of both the defendant Hotelier $\mathrm{Y}$ as well as the third parties who are holding

55 See, e.g., N.Y. C.P.L.R. § 5301-09 (McKinney's Consolidated Laws of New York Annotated) (providing for summary recognition of foreign money judgments). See further discussion infra at Section 4.

56 See Connecticut v. Doehr, 501 U.S. 1 (1991) (holding that a Connecticut statute authorizing prejudgment attachment of a defendant's real property upon the filing of an action, without prior notice or hearing, without a showing of extraordinary circumstances, and without a requirement that the plaintiff post a bond, violates the Due Process Clause of the Fourteenth Amendment). 
the defendant's property, as both the defendant and the third party garnishees would be entitled to notice and hearing, in which they may raise certain defenses. ${ }^{57}$ If the plaintiffs were seeking to restrain Hotelier Y's property in connection with a New York court action, the plaintiffs would have had to issue a restraining notice pursuant to New York Civil Practice Law and Rules § 5222, which provides that the party that issues a restraining notice must provide a notice to the obligor (in this case, Hotelier $Y$,) in a specific format that informs of the obligor's rights and in a manner designed for the obligor to actually receive notice. ${ }^{58}$ The plaintiffs also would have had to formally serve the restraining notice to any third party that holds the obligor's property. ${ }^{59}$ In response, Hotelier $Y$ would have had the opportunity to object to the restraint entirely, or claim specific exemptions. ${ }^{60}$ The third parties who hold Hotelier Y's property may likewise object to the restraint. ${ }^{61}$ Finally, before any property exchanges hands, there would be a court proceeding to ensure that the plaintiff is indeed entitled to receive the defendant's property. ${ }^{62}$

None of the above protections of the U.S. national debtor can be present in Scenario 2, because the United States has no mechanism for handling an interim relief that a foreign court issued. The absence of a system to address a foreign provisional order allows for a possibility of unruly self-help, of the kind in which the UK plaintiffs was engaged in Scenario 2 by sending informal letters that was not sanctioned by the court. For the sake of protecting constitutional Due Process rights and orderly administration of jus-

57 See N.Y. C.P.L.R. §§ 5222 \& 5225(b) (McKinney's Consolidated Laws of New York Annotated) (providing for issuance of restraining notice and payment or delivery of the property of judgment debtor). For a discussion on defenses against recognition and enforcement generally, see discussion infra at Section 4.

58 See N.Y. C.P.L.R. §§ 5222(d)-(g) (McKinney's Consolidated Laws of New York Annotated) (providing for issuance of restraining notice).

59 See N.Y. C.P.L.R. §§ 5222(a) \& 5222-a(b) (McKinney's Consolidated Laws of New York Annotated) (providing for issuance of restraining notice).

60 See N.Y. C.P.L.R. § 5222-a.

61 See, e.g., Verizon New England Inc. v. Transcom Enhanced Servs., Inc., 98 A.D.3d 203 (N.Y. App. Div. 1st Dep't 2012) (noting that in a C.P.L.R. article 52 turnover proceeding, the judgment creditor could not enforce a restraining notice against the third-party garnishee); JSC Foreign Economic Ass'n Technostroyexport v. Int'1 Dev. \& Trade Servs., Inc., 295 F. Supp. 2d 366 (S.D.N.Y. 2003) (holding that restraining notices would be properly limited to corporate assets).

62 See N.Y. C.P.L.R. § 5225. 
tice, it would be preferable to force the UK plaintiff to convert the Mareva order into a U.S. order first, such that the New York court may exercise oversight over the res located in New York in a way that minimizes the infringement of the U.S. citizen's property rights, and properly exercise jurisdiction over the third parties located within the New York court's jurisdiction.

\subsection{Creation of U.S.-Led Ecosystem of Private International Law}

The two benefits discussed in the foregoing may be characterized as "domestic" benefits that a provisional order recognition system confers to U.S. courts, in that such a system would allow the U.S. judiciary to vindicate justice and have effective administration of its courts. The third benefit, in contrast, may be characterized as an "international" or "diplomatic" benefit: establishing a streamlined procedure for recognizing foreign provisional orders which would also allow the United States to claim the leadership position in the formation of private international law, which it had lost over the past two decades.

To explain this point, a brief historical review of this area of international law is necessary. The United States did previously attempt to establish a procedure to recognize foreign provisional orders, and much more. American scholars have noted that, in the area of private international law, the United States was at a particular disadvantage. European courts had far-reaching jurisdiction that may subject U.S. nationals, and the resulting European judgments could be easily recognized and enforced in the United States. Meanwhile, European courts have been "rather stingy" with extending recognition and enforcement of U.S. court judgments. 63

To address this imbalance, in 1992, the U.S. proposed a new project that would result in a worldwide convention on jurisdiction, and the recognition and enforcement of foreign judgments, at the Hague Conference on private international law.64 The project

63 Kevin M. Clermont, An Introduction to the Hague Convention, in A GLOBAL LAW OF JURISDICTION AND JUDGMENTS: LESSONS FROM THE HAGUE 4 (John J. Barcelo III \& Kevin M. Clermont eds., 2002) (hereinafter "GLOBAL LAW OF JURISDICTION AND JUDGMENTS").

64 See Letter from the U.S. Department of State to the Secretary General of the 
resulted in the draft convention (the "Proposed Hague Convention") intended for adoption at the Hague Conference in 2000.65 The Proposed Hague Convention would have addressed the provisional order recognition issue and a lot more, as it was an ambitious proposal that would have given clarity for jurisdiction in a transnational case as well as the recognition and enforcement of final judgments. ${ }^{6}$ Specifically, the Proposed Hague Convention would have established a "whitelist" of jurisdictional bases, under which each signatory country must exercise jurisdiction, a "blacklist" under which each signatory must decline jurisdiction, and "gray zone" of jurisdictional bases that fall in between the two lists. ${ }^{67}$ The signatories to the Proposed Hague Convention would recognize each other's judgments, although they may choose to decline recognition of the cases arising from the "gray zone" of jurisdictional bases. 68 And (for the purpose of this paper) importantly, the Proposed Hague Convention would have provided for a mechanism for transnational issuance, recognition and enforcement of provisional protective measures. ${ }^{69}$ Under the Proposed Hague Convention, there are three grounds for a court to have jurisdiction to issue a provisional order: (1) the court has jurisdiction to adjudicate the main litigation; (2) the court is where property is located, in which the court may issue provisional orders with respect to that property, and; (3) the court is acting, on an interim basis, to protect a claim on the merits that is either pending or about to be brought by the requesting party, in which case the provisional or-

Hague Conference on Private International Law, May 5, 1992, http:// www.state.gov/documents/organization/65973.pdf [https://perma.cc/J227QSAZ].

65 See Barcelo \& Clermont, General Introduction, in GLOBAL LAW OF JURISDICTION AND JUDGMENTS, supra note 63, at 1.

66 For the text of the Proposed Hague Convention, see International Jurisdiction and Foreign Judgments in Civil and Commercial Matters, Prel. Doc. No. 7, Permanent Bureau of the Hague Conference on Private International Law, April 1997, http://www.hcch.net/upload/wop/jdgm_pd7.pdf [https://perma.cc/ LTA4-S4KF].

67 Clermont, An Introduction to the Hague Convention, in GLOBAL LAW OF JURISDICTION AND JUDGMENTS, supra note 63, at 6-7.

68 See id.

69 See Proposed Hague Convention, supra note 66, at $\$ 126$ (noting that "rules of jurisdiction concerning provisional and protective measures . . . are essential, especially in the international arena"); see also Clermont, An Introduction to the Hague Convention, in GLOBAL LAW OF JURISDICTION AND JUDGMENTS, supra note 63, at 7. 
der's enforcement is limited to the territory of signatory state to which the court belongs. ${ }^{70}$

The Proposed Hague Convention, had it come to fruition, would have gone a long way towards harmonizing critical parts of international civil litigation; namely, jurisdiction, provisional orders, and final judgments. However, after a decade of negotiation, the Proposed Hague Convention failed. ${ }^{71}$ Though the Proposed Hague Convention arguably failed for many reasons, ${ }^{72}$ I would argue that those reasons ultimately point to a single underlying cause: the dependency of the Proposed Hague Convention's path on the existing European system. ${ }^{73}$ The Proposed Hague Convention tracked the structure of the system that the EU nations used for harmonizing jurisdiction and recognition of judgments, and this path dependency gave rise to the suboptimal result.

The European system, enshrined in Brussels and Lugano Conventions, is a "double convention" that deals with jurisdiction and recognition of judgments (and provisional reliefs) at the same time. The double convention structure has the benefit of rationally streamlining the entire process of beginning and finishing litigation, and it made sense-or so it appeared at the time-for the

\footnotetext{
70 See Proposed Hague Convention, supra note 66, at $\mid$ | $81,114,126$. Note, however, that the Proposed Hague Convention did not address certain important issues involving transnational provisional orders, such as: (1) whether the jurisdiction of the court of one country to issue a provisional order precludes other countries from issuing a provisional order, or; (2) whether one country may issue a provisional order when the court before which the main action is pending, having jurisdiction to issue a provisional order, declines to issue the same provisional order. See Lawrence Collins, Special Problems, in THE HAgUe CONVENTION ON JURISDICTION AND JUdGMENTS: RECORDS OF THE CONFERENCE HELD AT NEW YORK UNIVERSITY SCHOOL OF LAW ON THE PROPOSED CONVENTION 104-106 (Andreas F. Lowenfeld \& Linda J. Silberman eds., 2001) (hereinafter "NYU CONFERENCE RECORD").

71 Some Reflections on the Present State of Negotiations on the Judgments Project in the Context of the Future Work Programme of the Conference, Prel. Doc. No. 16, Permanent Bureau of the Hague Conference on Private International Law, April 2002, http://www.hcch.net/upload/wop/gen_pd16e.pdf [https:// perma.cc/M562-UQDV].

72 See generally Peter D. Trooboff, Ten (and Probably More) Difficulties in Negotiating a Worldwide Convention on International Jurisdiction and Enforcement of Judgments: Some Initial Lessons, in GLOBAL LAW OF JURISDICTION AND JUDGMENTS, supra note 63 , at 262, 264.

73 Professor Andreas Lowenfeld noted that the Brussels Convention was "the starting point, if not quite the form book" for the Proposed Hague Convention. Andreas J. Lowenfeld, Setting the Stage, in NYU CONFERENCE RECORD, supra note 70 , at 3 .
} 
Proposed Hague Convention to be structured similarly. ${ }^{74}$ But once the negotiation began, it became clear that bundling all the concepts ensured none of concepts survived the scrutiny of the parties to the Proposed Hague Convention. Rather than separately pursuing some of the concepts on which the parties may have reached an agreement more easily, the Proposed Hague Convention insisted that all the operative parts of the Proposed Convention rose or fell together.

In the end, they fell. The United States found the jurisdictional provisions of the Proposed Hague Convention hugely problematic, as they would have upended more than a century of American precedents regarding jurisdiction and Due Process. ${ }^{75}$ The European nations, for example, would not tolerate the U.S. legal principle of general jurisdiction arising from continuous and systematic activities in the forum, and the attendant prospect of having more of its citizens involved in U.S. litigation, which is known for conducting wide-ranging and expensive discovery as well as for handing down huge damages. ${ }^{76}$ A case like Frummer v. Hilton Hotels International,77 in which the New York court asserted jurisdiction over a slip-and-fall that happened in a hotel in London because the London hotel advertised and booked reservations through a system in

\footnotetext{
74 For the discussion of the need to address these related concepts in a single multinational agreement, see, e.g., Stephen B. Burbank, Jurisdictional Equilibrium, the Proposed Hague Convention, and Progress in National Law, in GLOBAL LAW OF JURISDICTION AND JUDGMENTS, supra note 63, at 117. See also Lowenfeld, NYU CONFERENCE RECORD, supra note 70, at 2 ("[I]f a basic principle was that judgments of member states should be recognized if the first forum had jurisdiction, they had better agree on the rules of jurisdiction as well"). 265-66.

75 See Trooboff, GLOBAL LAW OF JURISDICTION AND JUDGMENTS, supra note 72, at

76 See Russell J. Weintraub, How Substantial is Our Need for JudgmentsRecognition Convention and What Should We Bargain Away to Get it?, 24 BROOK. J. INT'L L. 167, 187-188 (1998) ("Europeans do not see how doing business unrelated to the lawsuit could establish jurisdiction.") (internal quotation omitted); Eric Porterfield, A Domestic Proposal to Revive the Hague Judgments Convention: How to Stop Worrying About Streams, Trickles, Asymmetry, and a Lack of Reciprocity, 25 DUKE J. COMP. \& INT'L L. 81, 106-107 (2014) (“The European countries' real objection seems to be the conduct of American litigation, with its wide-ranging discovery and the prospect of large damages").

77 Frummer v. Hilton Hotels Int'l, Inc., 227 N.E.2d 852 (N.Y. 1967) (holding that since the British hotel corporation owned a reservation service, which conducted public relations and publicity work and transmitted requests for reservations to British hotel from New York, and thus was 'doing business' in New York, the British corporation was subjected to suit in New York).
} 
New York, is well-grounded in U.S. law, and unthinkable in Europe. ${ }^{78}$ Similarly problematic for the European parties was the "tag" jurisdiction, which the U.S. Supreme Court unanimously approved in Burnham v. Superior Court. ${ }^{79}$ In addition, some of the jurisdictional provisions in the Proposed Hague Convention-most notably, conferring jurisdiction in a tort action based on the place of injury-were likely to be unconstitutional under the Constitution of the United States. 80

In the end, these differences were too great to be bridged. In a letter to the Secretary General of the Hague Conference, dated February 22, 2000, the head of the U.S. delegation, Jeffrey Kovar, stated bluntly:

[T] he project as currently embodied in the October 1999 preliminary draft convention stands no chance of being accepted in the United States. Moreover, our assessment is that the negotiating process so far demonstrates no foreseeable possibility for correcting what for us are fatal defects in the approach, structure, and details of the text. In our view, there has not been adequate progress toward the creation of a draft convention that would represent a worldwide com-

78 But it must be noted that, through Helicopteros Nacionales de Columbia S.A. v. Hall, 466 U.S. 408 (1984), Goodyear Dunlop Tires Operations, S.A. v. Brown, 131 S. Ct. 2846 (2011) and Daimler A.G. v. Bauman, 134 S. Ct. 745 (2014), the U.S. Supreme Court has restricted the use of "doing business" as grounds for general jurisdiction. Commentators have noted that such cases would narrow the difference between the positions of the United States and the European Union. See Weintraub, supra note 76, at 186 n.117; Porterfield, supra note 76, at 83.

79 Burnham v. Superior Court of California, County of Marin, 495 U.S. 604 (1990) (holding that the exercise of personal jurisdiction based on service on the defendant while in the state comports with traditional notions of fair play and substantial justice).

80 See World-Wide Volkswagen Corp. v. Woodson, 444 U.S. 286 (1980) (holding that jurisdiction cannot always be exercised at the place of injury under the Due Process Clause). For discussion regarding the interaction between the Proposed Hague Convention and the US-EU differences tort jurisdiction, see Audrey Feldman, Rethinking Review of Foreign Court Jurisdiction in Light of the Hague Judgment Negotiations, 89 N.Y.U. L. REV. 2190 (2014). Had the Proposed Hague Convention passed, there is significant possibility that the Supreme Court of the United States would find the Convention unenforceable to the extent that it conflicted with Due Process. See Reid v. Covert, 354 U.S. 1 (1957) (holding that a treaty that provided for military trial over a civilian spouse of a soldier stationed abroad is unconstitutional to the extent it conflicts with the constitutional right for a trial by jury); Porterfield, supra note 76, at 109-110. 
promise among extremely different legal systems. ${ }^{81}$

The European nations, on the other hand, balked at the prospect of having to recognize U.S. judgments in their courts. Because U.S. courts have a reputation of handing down massive judgments, the non-U.S. parties feared the possibility that a U.S. judgment could be enforceable within their borders. ${ }^{82}$ Further, even without the Proposed Hague Convention, EU nations had little trouble having their judgments recognized in the United States because the U.S. has been a generous forum in recognizing foreign final judgments without requiring reciprocity, i.e. the requirement that the foreign country would also recognize the U.S. judgment. 83 Since the non-U.S. parties can readily obtain recognition of their judgments in U.S. courts, the non-U.S. parties did not have much more to gain by entering into the Proposed Hague Convention. The United States, on the other hand, has no additional incentive to offer to the non-U.S. parties to join. (One of the American delegates to the Hague Conference noted: "Less than facetiously, several in our delegation have suggested that the bargaining process might be somewhat different if the chair of the judiciary committees in the House or the Senate were to introduce in the United States Congress the Reciprocal Enforcement of Judgments Act.") ${ }^{84}$ With both the United States and the European Union finding fault in different parts, the Proposed Hague Convention was doomed. 85

81 Letter from Jeffrey D. Kovar, Assistant Legal Adviser for Private International Law to J.H.A. van Loon, Secretary General of the Hague Conference on Private International Law, Feb. 22, 2000, http://www.cptech.org/ecom/hague/ kovar2loon22022000.pdf [https://perma.cc/B6QF-BF7Q]; see also Arthur T. von Mehren, Drafting a Convention on International Jurisdiction and the Effects of Foreign Judgments Acceptable Worldwide: Can the Hague Conference Project Succeed?, in GLOBAL LAW OF JURISDICTION AND JUDGMENTS, supra note 63, at 282.

82 See Trooboff, supra note 72, at 267.

83 Clermont, supra note 63, at 5 ("But the United States has little bargaining power. It needs a convention, while the Europeans have little to gain over their presently favorable situation.").

84 Trooboff, supra note 72, at 264. The proposed Foreign Judgments Recognition and Enforcement Act, which is federal legislation that the American Law Institute prepared in response to the failure of the Proposed Hague Convention, does exactly that by requiring reciprocity in recognition of a foreign judgment. See American Law Institute, RECOGNITION AND ENFORCEMENT OF FOREIGN JUdGMENTS, ANALYSIS AND PROPOSED FEDERAL STATUTE, at xiii-xiv.

85 It is worth noting that two subsequent developments mitigated the failure of the Proposed Hague Convention. First, the Hague Conference promulgated the Convention on Choice of Court Agreements (the "Choice of Court Conven- 
My view is that, ultimately, the Proposed Hague Convention failed because it hewed too closely to EU's Brussels and Lugano Conventions. Like the Brussels Convention and the Lugano Convention, the Proposed Hague Convention bundled the problems of jurisdiction, recognition of judgment, and provisional reliefs in the same package. Negotiation and compromise generally require the opposing parties to meet halfway. However, the Proposed Hague Convention was essentially asking the United States to travel most of the way, while the European Union stayed put. Signing onto an expanded version of the Brussels and Lugano Conventions would have incurred comparatively little cost to the European Union, while the same would have incurred significant cost to the United States, which would have to fundamentally upend the century-old U.S. jurisprudence regarding personal jurisdiction and Due Process. ${ }^{86}$ In the end, the United States refused to travel that distance, which led to the failure of the Proposed Hague Convention.

Perhaps there is a different way. The challenge for the United States is to induce the European Union to meet halfway. To that end: what if the U.S. changed the center of gravity on the negotiating table? What if the United States began creating an international judicial system that runs parallel to the Brussels and Lugano Conventions? Going back to the negotiating table for the Proposed Hague Convention with a number of states within the U.S.-led judicial ecosystem, whose scale of economy and global reach would

tion"), which came into effect on October 1, 2015. The Choice of Court Convention mandates that, subject to certain exceptions, a court designated by a choice of court clause in a contract must exercise jurisdiction over a dispute regarding the contract, and all other courts must relinquish jurisdiction. See Hague Conf. of Private Int'l Law, Convention on Choice of Court Agreements (Concluded June 30, 2005) at Arts. 5-6, https://assets.hcch.net/docs/510bc238-7318-47ed-9ed5e0972510d98b.pdf [https://perma.cc/A9NW-5ZLT]. A judgment rendered under the Choice of Court Convention is to be given recognition and enforcement among contracting states. See id. at Art. 8-9. Second, negotiations for a reduced version of the Proposed Hague Convention, which would only govern the recognition and enforcement of judgments (and not jurisdiction, except to the extent that a jurisdictional filter may apply to the judgments) resumed recently in 2012. See Council on General Affairs and Policy of the Conference (Apr. 17-20, 2012), Hague Conf. on Private Int'l Law, Conclusions and Recommendations Adopted by the Council at 3-4 (Apr. 2012), http://www.hcch.net/upload/wop/gap2012concl en.pdf [https://perma.cc/2B3F-3FTR]. Notably for the purpose of this paper, neither the Choice of Court Convention nor the reduced version of the Proposed Hague Convention addresses the issue of recognizing and enforcing foreign provisional orders.

86 See supra, text accompanying note 80. 
be irresistible to the EU, and would provide the United States with much more leverage. Building an international system for recognition of foreign provisional orders may be the first step in that series of small steps that would lead to the creation of the U.S.-led judicial ecosystem. Indeed, taking this incremental step may even induce individual European states to join in the U.S.-led system, which may lead to greater cooperation in the future.

De-coupling the recognition of foreign provisional orders from other topics within the Proposed Hague Convention solves much of the difficulties that became apparent during the negotiation of the Proposed Hague Convention. First, unlike with the Proposed Hague Convention's allocation of jurisdiction, recognition of foreign provisional orders is minimally disruptive to the existing U.S. law. In determining whether a particular foreign provisional order should receive recognition in the United States, U.S. courts can readily borrow from pre-existing bodies of American law, depending on the precise mechanism through which foreign provisional orders would be recognized. ${ }^{87}$ For example, if the U.S. courts judicially craft a mechanism for the recognition of foreign provisional orders, the forum non conveniens standard may be borrowed. 88 That is, if the case sub judice would satisfy the forum non conveniens standard but for the fortuitous presence of defendant's assets in the U.S. court's jurisdiction, the U.S. court has relatively little interest in being involved in the case. In such a case, the U.S. court may decide to give recognition to a foreign provisional order, since under the forum non conveniens standard, the U.S. court was unlikely to exercise jurisdiction at any rate. For another example, if the U.S. legislatures-either the U.S. Congress or various state legislatures-should pass a statute that provides for the recognition of foreign provisional orders, adjudication of the recognition of foreign provisional orders can borrow from the existing case law regarding the recognition of foreign final judgments. ${ }^{89}$

Second, unlike U.S. final judgments, U.S. provisional orders do not have the reputation of being unduly harsh or liberally doled out. Although the full comparative overview of various provision-

\footnotetext{
87 For discussion on various possible mechanisms through which recognition of foreign provisional orders may be achieved, see infra Section 4.

88 See Piper Aircraft, 454 U.S. at 241-243; Whytock, supra note 47.

89 For discussion on the prospect of legislative solution for recognition of foreign provisional orders, see infra Section 4.2.
} 
al reliefs available worldwide is beyond the scope of this paper, it appears likely that UK provisional orders, which include the infamous Mareva and Anton Piller orders (dubbed "nuclear weapons of the law,") have the dubious distinction of being the most feared provisional orders in the world. ${ }^{90}$ Because foreign countries do not particularly fear giving recognition to U.S. provisional orders, it is easier for the United States to establish a system of mutual and reciprocal recognition of provisional orders with a foreign state. Finally, unlike the case with final judgments, the U.S. currently does not yet have a system of recognizing foreign provisional orders which would incentivize foreign nations to join the U.S.-led system of giving recognition to provisional orders, since they would stand to gain the additional benefit of having their court's provisional orders given recognition in the United States.

Reciprocity is the key concept for this strategy: the United States needs a system in which it would recognize provisional orders issued by a foreign court, and the same foreign court would recognize the U.S. provisional order in return. In a decentralized system that depends on horizontal negotiations rather than a topdown directive, reciprocity plays a critical role in harmonizing the laws of different legal systems. For example, France abandoned its practice of invasively reviewing foreign judgments in 1964 as Germany placed a reciprocity requirement in recognizing and enforcing foreign judgments. ${ }^{91}$ Similarly, with a recognition system that requires reciprocity, the U.S. can begin constructing its own international jurisprudential ecosystem, which would eventually develop into a judicial collective similar to the one existing in the European Union under the Brussels and Lugano Conventions.

The multinational system of giving recognition to provisional orders would eventually spill over into harmonization of other areas, as the full harmonization of provisional orders cannot help but

\footnotetext{
90 Kern Alexander, The Mareva Injunction and Anton Piller Order: The Nuclear Weapons of English Commercial Litigation, 11 FLA. J. INT'L L. 487, 488 (1997). For discussion regarding potential extraterritorial abuses of Mareva orders, see Wilson, supra note 19.

91 See Jenny S. Martinez, Towards an International Judicial System, 56 STAN. L. REV. 429, 512 (2003) (arguing that courts should apply a sort of "antiparochialism" canon in deciding process-related issues in transnational cases: specifically, they should choose a course that furthers the development of an ordered, functional, international judicial system through doctrines that foster dialogue among participants in the system).
} 
involve other areas of the law. For example, an international antisuit injunction-with which the court of one country orders the party to stop pursuing litigation in another country-is a provisional relief that essentially demands harmonization of jurisdiction between the two countries. ${ }^{92}$ Recognition of foreign anti-suit injunctions necessarily means that there will be harmonization of jurisdictions between the United States and the foreign forum. Over time, this type of spillover would eventually develop into its own international judicial ecosystem, akin to the ecosystem created by Brussels and Lugano Conventions, but under U.S. leadership. Such an ecosystem would provide for a streamlined procedure for transnational litigation that covers the beginning of litigation (jurisdiction), the end of litigation (enforcement of judgment), and the events in between (provisional reliefs).

The best initial target signatories for this ecosystem would be U.S.-friendly trade partners that are not within the European order, such as Japan, South Korea, Australia, New Zealand, and Turkey. In many ways, the recently concluded Trans-Pacific Partnership (TPP) could serve as a model. ${ }^{93}$ The signatories for the TPP include Japan, Australia, Canada, Mexico, Malaysia, Peru, Vietnam, New Zealand, Chile, and Singapore - all U.S.-friendly economies of significant size that are not within the Brussels and Lugano Conventions order. The TPP also includes important international law provisions, most notably a dispute settlement mechanism between an investor and a state. ${ }^{94}$ In the future rounds of multilateral trade pacts, such as the TPP, one can easily imagine a mutual recognition system of provisional reliefs becoming one of the agreed provisions. As the U.S.-led free trade ecosystem, backed by U.S.-led pri-

\footnotetext{
92 Arthur von Mehren, AdjudicAtory Authority IN PRIVATE INTERnAtional LAW: A COMPARATIVE STUDY 279 (2007) (anti-suit injunction is "an instrument of fine-tuning" competing jurisdictions). It must be noted that an anti-suit injunction is mostly a feature of common law jurisdictions, as most civil law jurisdictions reject the use of anti-suit injunctions. See id. However, as discussed infra, the U.S.led judicial ecosystem would necessarily include many significant common law jurisdictions that are outside of the order created by the Brussels and Lugano Conventions, such as Australia, Canada, and New Zealand.

93 Trans-Pacific Partnership, full text, https://ustr.gov/trade-agreements/ free-trade-agreements/trans-pacific-partnership/tpp-full-text [https://perma.cc/ FJ3G-H2FE].

94 Dispute Settlement, Trans-Pacific Partnership Ch. 28, https://ustr.gov/ sites/default/files/TPP-Final-Text-Dispute-Settlement.pdf [https://perma.cc/ K9XH-JPA9].
} 
vate international law, grows in size, the network effect would increase the pressure upon the rest of the world to join.

Eventually, the size and influence of the U.S.-led private international law ecosystem would become enough to incentivize the European nations to step out of their comfort zone within the Brussels and Lugano Conventions system. When that does happen, the parties may revisit the Proposed Hague Convention structure and address the entire lifecycle of transnational litigation (i.e. jurisdiction, provisional relief, judgment recognition, and enforcement), or engage in the gradual harmonization of the components of a transnational litigation.

\section{DESIGNING THE SYSTEM OF RECOGNITION AND ENFORCEMENT OF FOREIGN PROVISIONAL ORDERS: THREE POSSIBILITIES}

Having discussed the necessity for establishing a system of recognizing foreign provisional orders, this part of the paper will describe and assess three possible routes forward: judicial, legislative, and treaty-based. All three routes may lead the U.S. law toward having a coherent system of recognizing and enforcing foreign provisional orders - that is, all three routes may produce a system equipped with all the essential features required to reap the benefits of giving recognition to foreign provisional orders. Such features may include: a summary procedure to ensure expeditious execution of the provisional order; defenses that the party resisting the recognition and enforcement of the foreign provisional order may raise, in a manner consistent with the Due Process Clause of the U.S. Constitution; mandatory and discretionary bases under which the court may respond flexibly in recognizing and enforcing foreign provisional orders; a reciprocity requirement in order to induce foreign legal systems to recognize U.S. provisional orders, etc. However, in order to fully realize the triple benefits of establishing this system discussed above, and in consideration of the reality of the current legal landscape, as well as the tendencies of the institutions that correlate to these three possible paths, it appears that the legislative option is superior to the judicial one, and the treaty-based option is superior to both the other two. 


\subsection{Judicial Option: Resurrection of Hilton v. Guyot}

The judicial option envisions a gradual construction of the system of recognizing foreign provisional orders through a series of case law. There is already precedent for constructing such a system. The possibility of judicially creating a system of recognizing foreign provisional orders flows from the Supreme Court case of Hilton v. Guyot, from 1895.95

In Hilton, the Supreme Court considered whether U.S. courts may give recognition to a French judgment. The Supreme Court answered in the negative, while acknowledging the possibility that a foreign judgment may be given recognition in the United States based on the principle of international comity. But in the case of a judgment from France, according to the Supreme Court, international comity was inapplicable because international comity required "mutuality and reciprocity," and the French court at the time did not recognize the U.S. judgments. Thus, Hilton propounded two important principles upon which it may be possible to construct a system of giving recognition to foreign provisional orders: (1) international comity allows U.S. courts to give recognition to foreign court orders, so long as; (2) the foreign court also reciprocates by giving recognition to U.S. court orders in return. Based on these two principles, the U.S. courts may begin to fashion a systematic approach to recognizing foreign provisional orders through case law.

The judicial option, however, faces major challenges. The first challenge is the current landscape of the U.S. law. Subsequent developments in American law have rendered the Hilton principles all but forgotten. In 1938, the Supreme Court in Erie R.R. Co. v. Tompkins held that there is no general federal common law, and that federal courts with diversity jurisdiction must follow the substantive law of the state in which they are sitting. ${ }^{96}$ Because there was no federal statute or treaty governing judgment recognition, federal courts ignored the holding in Hilton $v$. Guyot and followed instead the state law on foreign judgment recognition. ${ }^{97}$ Instead of

95159 U.S. 113 (1895).

96304 U.S. 64 (1938).

97 See generally Katherine R. Miller, Playground Politics: Assessing the Wisdom of Writing a Reciprocity Requirement into U.S. International Recognition and Enforcement Law, 35 GEO. J. INT'L L. 239, 251 (2004). 
the Hilton principles, 33 states and the District of Columbia have adopted some version of the Uniform Foreign Money Judgment Recognition Act ("UFMJRA"), which governs whether a foreign judgment may receive recognition from a U.S. court. ${ }^{98}$ Although there is no equivalent of UFMJRA for foreign provisional orders, one can make a strong argument that under Erie, federal courts cannot fashion a system of giving recognition to foreign provisional orders absent a federal statute, because there is no general federal common law. Given that the vast majority of transnational litigation happens at the federal level, this is a significant roadblock.

Significant, but not insurmountable. It may be possible for state courts to fashion a system of giving recognition to foreign provisional orders. As discussed previously, some state courts have held that foreign provisional orders, in relation to matrimonial actions, may be given recognition. 99 Those states would only have to extend the recognition to provisional orders in other types of actions. Alternatively, federal courts may yet decide to federalize the law regarding recognition of foreign court orders, based on the plenary powers regarding foreign affairs, which was given to the federal government in the United States Constitution. Although Erie held that there was no general federal common law, the Supreme Court has recognized that certain narrowly defined areas involving "uniquely federal interests" are regulated by federal common law, and the state law in those areas is preempted and replaced. ${ }^{100}$ The conduct of the United States foreign relations, it has been held, is one of the areas that implicates such uniquely federal interests. 101 The federal courts may determine that recognition of

98 See Gregory H. Shill, Ending Judgment Arbitrage: Jurisdictional Competition and the Enforcement of Foreign Money Judgments in the United States, 54 HARV. INT'L L.J. 459, 491-498 (2013) (explaining the UFMJRA). Even states that did not pass the UFMJRA usually give liberal recognition for foreign judgments under the state's Common Law. See id. at 498-499.

99 See supra note 6.

100 Boyle v. United Technologies Corp., 487 U.S. 500, 504 (1988). Even in such "uniquely federal" areas, federal common law will be fashioned only to prevent "significant conflict" between state laws and federal policies and interests. See O'Melveny \& Myers v. FDIC, 512 U.S. 79, 87-88 (1994).

101 See, e.g., Banco Nacional de Cuba v. Sabbatino, 376 U.S. 398, 407, 423 (1964) (citing Baker v. Carr, 369 U.S. 186 (1962)) (noting that the Supreme Court granted certiorari in this instance since "the issues involved bear importantly on the conduct of the country's foreign relations," however, not "every case or controversy which touches foreign relations lies beyond judicial cognizance"); Zschernig v. Miller, 389 U.S. 429, 441 (1968) (noting that State law may have "a 
foreign provisional orders involves "uniquely federal interests" in the regulation of foreign relations, and thus begin to craft a system of recognition.

Practical considerations, however, lead one to doubt that the U.S. courts will attempt to meet this challenge. Therein lies the second challenge for the judicial option: the fundamental cognitive challenge that U.S. jurisprudence has with respect to transnational litigation. Because of its long tradition of handling conflict-of-law cases in the context of different states belonging to the same federation, American courts generally do not distinguish transnational litigation from inter-state litigation. ${ }^{102}$ Rather than approaching transnational litigation as an independent category deserving of legal analysis that examines its peculiarity, U.S. courts tend to equate foreign nations with one of its states, with little to no separate considerations for international comity. ${ }^{103}$ Professor Stephen Burbank noted that under U.S. law, neither international litigation nor international civil litigation is a discrete field, as U.S. courts "have brought to bear doctrine and techniques developed in domestic cases."104 While hope springs eternal, it does not appear likely to the practical-minded that any minute now, the U.S. courts will break their long-standing habit of ignoring the meaningful dif-

direct impact upon foreign relations and may well adversely affect the power of the central government to deal with those problems," and in that instance must be limited).

102 See Trooboff, supra note 72 , at 264, observing that:

In general, American courts have not subjected judgments from the courts of other nations to a separate test to determine whether they are entitled to recognition and enforcement. Rather, the courts of the United States revert to acting as they would if they were confronting a domestic case that raised an issue as to whether the originating court had properly asserted jurisdiction.

See also Stephen B. Burbank, Practice and Procedure: the World in Our Courts, 89 MicH. L. REV. 1456, 1458-59 (1991) (raising doubt as to whether transnational litigation may be considered a separate field within U.S. law); Bermann, supra note 12 , at 560 (noting U.S. court's indifference toward parties' nationalities in granting provisional relief).

103 Another example of this trend in American jurisprudence: Restatement (Second) of Conflict of Laws calls for recognition of foreign injunctive orders because "American courts . . . have usually given the same measure of respect to judgments rendered in foreign nations ... that they give to judgments rendered in sister States." RESTATEMENT (SECOND) OF CONFLICT OF LAWS § 102, cmt. g (AM. LAW INST. 1971).

104 Burbank, supra note 102, at 1459. 
ferences between inter-state litigation and transnational litigation in order to construct a system of giving recognition to foreign provisional orders.

\subsection{Legislative Option: UFMJRA as a Model}

The legislative option would involve the legislatures of the United States - either the Congress, the federal legislature, or various state legislatures-passing legislation that provides for systematic recognition of foreign provisional orders. This option benefits from having the ready model from which to emulate - that is, the Uniform Foreign Money Judgment Recognition Act (UFMJRA). UFMJRA is a model act promulgated by the National Conference of Commissioners on Uniform State Laws. Thus far, 33 states and the District of Columbia have adopted some variant of the UFMJRA. ${ }^{105}$ Under the Uniform Foreign Money Judgment Recognition Act, parties may petition a U.S. court to recognize a money judgment rendered by a foreign court. In general, as long as the foreign judgment is "final, conclusive, and enforceable where rendered," 106 an American court will give recognition to the judgment and treat the foreign judgment as if the court itself rendered the judgment. UFMJRA only recognizes a limited set of exceptions, including the foreign court's lack of personal jurisdiction over the defendant, and the foreign judgment coming from a legal system that does not provide impartial tribunals. Crucially, however, UFMJRA lacks the reciprocity requirement, allowing the recognition of for-

105 Shill, supra note 98, at 491-98. Nine states (Alaska, Connecticut, Maryland, Missouri, New Jersey, New York, North Dakota, Pennsylvania, and Virginia) adopted the version of UFMJRA proposed in 1962. See id. at 492 n.164. Eighteen States (Alabama, California, Colorado, Delaware, Hawaii, Idaho, Illinois, Indiana, Iowa, Michigan, Minnesota, Montana, Nevada, New Mexico, North Carolina, Oklahoma, Oregon, and Washington) and the District of Columbia adopted the later version of UFMJRA (called Uniform Foreign-Country Money Judgments Recognitions Act), proposed in 2005. See id. at 492 n.165. Compared to the 1962 UFMJRA, the 2005 UFMJRA has two more discretionary grounds for non-recognition and specifically allocates the burden of establishing nonrecognition grounds on the party resisting recognition. See id. at 493-97. Six states (Florida, Georgia, Massachusetts, Maine, Ohio, and Texas) adopted tailored statutes that were largely based on the 1962 UFMJRA, but with additional grounds for non-recognition, including lack of reciprocity. See id. at 497.

106 CIBC Mellon Trust, 100 N.Y.2d at 221 (applying New York State's version of the UFMJRA). 
eign judgments rendered from a jurisdiction that does not in turn recognize U.S. judgments. 107

The legislative option would involve a statute similar to the UFMJRA, but with foreign provisional orders instead of foreign money judgments. ${ }^{108}$ As a precondition for recognition, the legislation would require that a foreign provisional order be valid and enforceable where issued, and provide for only a limited set of exceptions such as lack of impartial tribunals. In order to gain the third benefit of building a U.S.-led judicial ecosystem, the legislation providing for recognition of foreign provisional orders would require reciprocity from other countries, unlike the UFMJRA.

The imperfection of the UFMJRA as a model, however, makes the legislative option an inferior one. One of the major imperfections is that UFMJRA is not a federal statute, applicable uniformly throughout the United States. As noted earlier, the UFMJRA is a state law, developed in response to the constraints imposed by Erie and the lack of general federal common law. The same constraints likely prevent our proposed legislation from becoming a federal statute. 109 As noted earlier, there is sufficient room to argue that recognition of foreign court orders - be they an interim relief or a final judgment-falls within the domain of the federal government, under the U.S. Constitution, as it implicates foreign affairs. ${ }^{110}$ In-

107 The six states that enacted their own version of the UFMJRA - i.e. Florida, Georgia, Massachusetts, Maine, Ohio and Texas - included additional grounds for non-recognition, which includes of lack of reciprocity. In Florida, Maine, Ohio and Texas, lack of reciprocity is a discretionary ground for non-recognition; in Georgia and Massachusetts, it is a mandatory ground. See Shill, supra note 98, at 497.

108 Another potential model of note is the model statute developed by American Law Institute ("ALI"), titled Foreign Judgment Recognition and Enforcement Act (the "Proposed ALI Act"). The Proposed ALI Act does require reciprocity as a precondition for recognition of final judgments. See discussion supra at note 84 . For general discussion regarding ALI's model statute, see Miller, supra note 97, at 26-287; Shill, supra note 98, at 509-10.

109 See Johnston v. Compagnie Generale Transatlantique, 242 N.Y. 381, 386387 (1926) (holding that because recognition of a foreign judgment was "of private right rather than public relations," recognition of foreign judgments only depended on the laws of the State of New York, without reference to the authority of the Supreme Court of the United States); Somportex Ltd. v. Philadelphia Chewing Gum Corp., 453 F.2d 435, 440 (3d Cir. 1971), cert. denied 405 U.S. 1017 (1972) (noting that judgements from sister states are "entitled to full faith and credit," while foreign court judgments are merely "subject to principles of comity" under Pennsylvania law).

110 See supra text accompanying Section 4.1. 
deed, the American Law Institute makes that very argument in its support for the model law, titled Foreign Judgment Recognition and Enforcement Act, which would federalize the recognition of foreign final judgments. ${ }^{111}$ But given the trend in the U.S. law with respect to transnational litigation discussed in the foregoing, it appears less than likely that there would be a sudden about-face on this front, as federalization of the recognition laws would represent a major departure from the current practice.

An alternative legislative option is to pass legislation authorizing recognition of foreign provisional orders in each of the 50 state legislatures. Given the relative success of the UFMJRA, the stateby-state approach is a viable path. Yet the state-by-state approach would suffer from the same shortcomings that the UFMJRA does; namely the state-to-state variations. A significant minority of American states-seventeen in total-has not passed the UFMJRA.112 In these states, there is no expedited procedure for recognition of a foreign judgment; a civil action is required for the recognition of a judgment. There is little reason to expect that these states would feel the need to pass a law that provides for summary recognition of foreign provisional orders. In addition, not-insignificant differences exist among the versions of the UFMJRA adopted by the thirty-three states and the District of Columbia, such as reciprocity requirements, mandatory and discretionary grounds for non-recognition, and so on. ${ }^{113}$

These shortcomings do not necessarily doom the legislative option. In practicality, having a recognition law passed in just a handful of U.S. states that have much of the nation's connections with the stream of international trade-such as California, New York, and Illinois - would go a long way toward achieving the benefits of giving recognition to foreign provisional orders. But the shortcomings do exist with the legislative option, which makes the treaty-based option the most attractive one.

111 See American Law Institute, supra note 84, at 3-4 (noting that the proposed legislation would return the U.S. "to a national standard for recognition and enforcement of foreign judgments").

112 These states are: Arizona, Arkansas, Kentucky, Louisiana, Mississippi, Nebraska, New Hampshire, Rhode Island, South Carolina, South Dakota, Tennessee, Utah, Vermont, West Virginia, Wisconsin and Wyoming. See Shill, supra note 98, at 498 n.194.

113 See supra note 105 and accompanying text. 


\subsection{Treaty-Based Option: Flexibility and Customization}

The treaty-based option envisions a bilateral or multilateral treaty into which the United States would enter with foreign nations. ${ }^{114}$ Compared to the judicial or legislative options, the treatybased option is superior in several aspects.

First, the treaty-based option is national in scope. Because of the Erie doctrine, federal courts or Congress may be hesitant to promulgate a national standard for recognizing foreign provisional orders. Not so with the executive branch: as discussed above, the United States is already a party to several bilateral or multilateral treaties that give recognition to foreign provisional orders, albeit in limited areas of law, such as drug crimes or securities fraud.115 The recognition requirement, established by a treaty or a functionally equivalent agreement, would be applied nationally throughout the United States and pre-empt any inconsistent state law. ${ }^{116}$

Second, the treaty-based option can bind foreign countries directly. This has significant implications with respect to the third benefit of having a system of recognition for foreign provisional orders, namely building a U.S.-led judicial ecosystem. Building such an ecosystem requires other countries to join the U.S.-led system. The judicial and legislative options cannot achieve this directly, as the U.S. courts and legislatures have no authority over foreign governments. At best, the reciprocity requirement in the judicial and legislative options can only incentivize (rather than mandate) the foreign courts to recognize the U.S. interim reliefs. In contrast, a treaty could directly impose the obligation to give recognition to U.S. provisional orders upon a foreign court.

Third, the treaty-based option affords the maximum flexibility necessary to bridge the myriad of differences that exist between the

114 The term "treaty," for the purpose of this paper, may encompass functionally equivalent international agreements such as a so-called "CongressExecutive" agreement or an Executive agreement. See RESTATEMENT (THIRD) OF FOREIGN RELATIONS LAW § 303 (AM. LAW INST. 1987) .

115 See supra text accompanying note 5.

116 See United States v. Belmont, 301 U.S. 324, 331 (1937) (noting that treaties made by the national government "cannot be subject to any curtailment or interference on the part of the several states"); RESTATEMENT (THIRD) FOREIGN RELATIONS LAW §§ 111(3) \& 303(4) (AM. LAW INST. 1987) ("courts of the United States are bound to give effect to ... . international agreements of the United State . ..."). 
legal systems of the United States and elsewhere. ${ }^{117}$ That flexibility would apply in several different contexts. For example, a treatybased system can respond to the different variations in law that may arise between the U.S. and the foreign state. A bilateral treaty, in particular, can respond far better to the differences in the legal concerns of the U.S. and the counter-signatory state than a multinational convention could. For example, the United States would be hesitant to recognize and enforce a foreign provisional order that restricts political speech, due to its strong speech protection ensured under the First Amendment of the U.S. Constitution. ${ }^{118}$

A treaty-based system may also be flexible regarding the types of provisional orders, so as to prioritize the less controversial type of provisional measures. ${ }^{119}$ Among the many different types of provisional orders, arguably, the least controversial is the preliminary attachment of defendants' property in order to secure the potential final judgment, because virtually every jurisdiction has such a provisional relief. ${ }^{120}$ The treaty regime may begin with mutual recognition of such attachment orders, and then gradually move onto more contentious areas, such as preliminary cease-and-desist orders. Such incremental escalation would culminate at what is, arguably, the most controversial provisional order of all, namely anti-suit injunctions. ${ }^{121}$ Here, one can see clearly how taking the first step in constructing a system of mutual recognition of foreign provisional orders logically leads to constructing a private interna-

\footnotetext{
117 For a discussion on how bilateral treaties can navigate variations between different legal systems, see Lindsay Loudon Vest, Cross-Border Judgments and Public Policy Exception: Solving the Foreign Judgment Quandry by way of Tribal Courts, 798 U. PENN. L. REV.797, 813-814 (2004) (noting that through bilateral treaties, countries "have the power to pick and choose which signatory nations' judgments to recognize," thus the judgements of court systems recognized as being "fraught with corruption" need not be reciprocally enforced).

118 See U.S. Const. amend. I (mandating that "Congress shall make no law ... abridging the freedom of speech"). Compare RESTATEMENT (THIRD) OF THE FOREIGN RELATIONS LAW OF THE UNITED STATES § 482(2)(d) (AM. LAW INST. 1987) (stating that U.S. courts need not recognize a foreign final judgment if "the cause of action on which the judgment was based, or the judgment itself, is repugnant to the public policy of the United States or of the State where recognition is sought").

119 The UMFJRA is an example of the similar line of thought, as the law only applies to foreign money judgments and not to, say, injunctive orders.

120 See, e.g., supra text accompanying notes 34-37.

121 Bermann, supra note 12, at 615 (stating that the use of anti-suit injunctions may "precipitate international judicial warfare," thus its international use should be "sharply curtailed").
} 
tional legal system in other areas of the law. ${ }^{122}$ Because enforcing foreign anti-suit injunctions naturally flows into the idea of harmonizing multiple international jurisdictions, the highly developed system of recognizing foreign provisional orders may serve as the first step in the U.S.-led evolution of the greater body of private international law.

\section{CONCLUSION: TOWARD A PRACTICAL SOLUTION}

The U.S. legal system is sorely in need of a system to address foreign provisional orders in a coherent manner. Constructing a system of recognizing and enforcing foreign provisional orders would serve the U.S. interests in several ways. In addition to the inherent benefits that provisional orders provide to litigation, such a system would promote judicial economy and give rise to the U.S.-led private international law ecosystem. Although such a system may be created through any one of the judicial, legislative or treaty-based paths, the treaty-based option would provide the maximum flexibility necessary for this system to come to fruition.

122 See discussion supra text accompanying Section 3.4. 